\title{
HUBUNGAN KURANG ENERGI KRONIS (KEK) PADA IBU HAMIL DENGAN KEJADIAN BERAT BAYI LAHIR RENDAH (BBLR) DI WILAYAH KERJA PUSKESMAS RAJADESA TAHUN 2019
}

\author{
Siti Fatimah ${ }^{1}$, Nopi Tri Yuliani ${ }^{2}$ \\ ${ }^{1,2}$ Program Studi DIII Kebidanan, Fakultas Ilmu Kesehatan, Universitas Galuh \\ tievan72@gmail.com,nopi3yuliani@gmail.com \\ (Diterima 25-11-2019; disetujui 18-11-2019; dipublish 26-11-2019)
}

\begin{abstract}
Abstrak
Anemia dalam kehamilan merupakan masalah nasional karena mencerminkan nilai kesejahteraan ekonomi masyarakat. Target global SDG's (Sustainable Development Goals) adalah menurunkan AKI menjadi 70 per $100.000 \mathrm{KH}$. Mengacu dari kondisi saat ini, potensi untuk mencapai target SDG's untuk menurunkan AKI adalah off track, artinya diperlukan kerja keras yang sungguh-sungguh untuk mencapainya (Pusat Data dan Informasi Kementerian Kesehatan RI, 2014). Tujuan penelitian ini adalah untuk mengetahui hubungan Kurang Energi Kronis (KEK) pada ibu hamil dengan kejadian Berat Bayi Lahir Rendah (BBLR) di Wilayah Kerja Puskesmas Rajadesa Tahun 2019. Metode penelitian ini menggunakan metode penelitian deskriptif korelatif dengan pendekatan cross sectional jumlah sampel sebanyak 66 orang. Sampel pada penelitian ini adalah diperoleh dengan menggunakan teknik total sampling. Hasil penelitian: Diketahui bahwa lebih dari setengahnya responden tidak mengalami kejadian KEK sebanyak 35 orang (53\%), diketahui bahwa lebih dari setengahnya responden mengalami kejadian BBLR sebanyak 41 orang $(62,1 \%)$, berdasarkan hasil uji statistik Chi Square, diketahui bahwa nilai P sebesar 0,000 lebih kecil dari nilai $\alpha(0,05)$, sehingga dapat disimpulkan bahwa terdapat hubungan antara kejadian KEK dengan kejadian BBLR. Saran: Diharapkan petugas kesehatan khususnya bidan agar lebih meningkatkan konseling dalam pelayanan kesehatan kepada ibu hamil sehingga ibu hamil dapat memperoleh informasi yang cukup tentang gizi terutama agar ibu tidak terkena Kurang Energi Kronis.

Kata Kunci : Hubungan KEK dengan BBLR
\end{abstract}

\begin{abstract}
Anemia in pregnancy is a national problem because it reflects the value of people's economic welfare. The global target SDGs (Sustainable Development Goal) is to reduce AKI to 70 per $100.000 \mathrm{KH}$. Refers to the current condition, the potential to reach the target of SDGs in reducing AKI is off track which means it needs hard work to achieve it (Data and Information Center of Indonesia Ministry of Health, 2014). This study attempts to know the relationship of less chronic energy (KEK) of pregnant women and low birth weight baby (LBWB) in the work area of Rajadesa community health center in 2019. This study used correlative descriptive with cross sectional approach involving 66 samples. These samples were gained through total sampling. This study found out that more than half of the respondents didn't experience the less chronic energy, 35 people (53\%); more than half of the respondents experienced less chronic energy, 41 people (62,1\%); based on Chi Square statistical experiment, the value of $P$ is 0,000 less than the value of $\alpha(0,05)$; so that it can be concluded that there is a relationship between less chronic energy and low birth weight baby. Moreover, it is suggested that health workers, especially midwifery, to enhance counselling on health services for pregnant women in obtaining sufficient information about nutrient so that the mother is not affected less chronic energy.
\end{abstract}

Keywords : relationship between less chronic energy and low birth weight baby 


\section{PENDAHULUAN}

World Health Organization (WHO) menjelaskan bahwa bayi yang megalami berat badan lahir rendah atau BBLR yaitu bayi yang terlahir dengan berat badan kurang dari 2500 gram, jumlah kejadian BBLR pada tahun 2011 adalah sebanyak $15 \%$ bayi di seluruh dunia (lebih dari 20 juta jiwa) lahir dengan BBLR (UNICEF, 2013). Pada tahun 2013 kasus BBLR mencapai $10,2 \%^{1,2,3}$.

Dinas Kesehatan Provinsi Jawa Barat tahun 2016 didapatkan bahwa jumlah BBLR di Jawa Barat sebanyak 18.997 dan jumlah kasus di Kabupaten Purwakarta sebanyak $0,015 \%$. Penyebab kematian yang diakibatkan oleh BBLR sejumlah 1298 bayi $^{3}$. Salah satu indikator Sustainable Development Goals (SDG's) pada 2030 adalah mengakhiri kematian bayi dan balita, Angka Kematian Bayi (AKB) 25 per 1000 Kelahiran Hidup (SDKI, 2012) target SDG's 2030 adalah sebanyak 25/ $1.000 \mathrm{KH}^{4}$.

Pada tahun 2017 angka kematian bayi di Kabupaten Ciamis sebanyak 126 dari 18.492 kelahiran hidup (laporan Puskesmas), sehingga didapatkan AKB sebesar 6.81 per $1.000 \mathrm{KH}$. Berdasarkan pencapaian tersebut maka terdapat kenaikan angka dari tahun sebelumnya (tahun 2016 sebesar 7.38 per $1.000 \mathrm{KH})^{2}$.

AKB di Indonesia diantaranya disebabkan oleh BBLR 29\%, diikuti dengan penyebab lainnya yaitu asfiksia $27 \%$ serta infeksi neonatus. Faktor penyebab AKB yang sering dikaitkan antara lain hal berikut terutama keberhasilan program KIA, KB, kondisi lingkungan, serta masalah sosial ekonomi ${ }^{2}$. Cakupan ibu hamil KEK pada tahun 2016 mendapatkan makanan tambahan sebanyak $79.1 \%$ dari target $50 \%$ dan sudah melebihi target. Penentuan target 50\% ditentukan dari jumlah ibu hamil yang mengalami KEK yang ada di Indonesia.

Di Indonesia tahun 2013 berdasarkan hasil Riset Kesehatan Dasar (Riskesdas), kasus
Kurang Energi Kronis (KEK) didasarkan oleh tingginya angka anemia sebesar $23,9 \%$, anemia ibu hamil $37,1 \%$, dan 20,8\% KEK dialami pada Wanita Usia Subur (WUS), KEK pada ibu hamil 24,2\%. Angka KEK mengalami peningkatan dari tahun 2010 yaitu 31,3\% menjadi $38,5 \%$ di tahun $2013^{3}$.

Menurut Badan Puslitbang Gizi dan Makanan Depkes RI di Jawa Barat angka kejadian KEK 30,6\% pada tahun 2016. Angka Kejadian KEK di Kabupaten Ciamis berdasarkan Profil kesehatan Kabupaten Ciamis ibu hamil kurang energi kronis sebesar 18,2\% (Profil Kesehatan Dinas Kesehatan Kabupaten Ciamis, 2016). Pada tahun 2017 kejadian KEK di Puskesmas Rajadesa sebanyak 102 kasus dari 1031 orang ibu hamil dan angka kejadian kasus BBLR pada tahun 2017 di Puskesmas Rajadesa sebanyak 52 kasus (Dinas Kesehatan Kabupaten Ciamis, 2017) ${ }^{2}$.

Data diatas menunjukan bahwa ada peningkatan kasus KEK di Puskesmas Rajadesa sebanyak 11 kasus meskipun untuk kasus BBLR nya mengalami penurunan sebanyak 4 kasus. Berdasarkan studi pendahuluan yang dilakukan peneliti ke Dinas Kesehatan Kabupaten Ciamis pada tanggal 15 Januari 2019 didapatkan total bayi yang mengalami BBLR tahun 2018 dari 37 Puskesmas di Kabupaten Ciamis kasus BBLR paling tinggi yaitu di Puskesmas Rajadesa sebanyak 48 kasus. Selain angka BBLR yang tinggi, kejadian KEK di Puskesmas Rajadesa juga memperoleh angka tertinggi yaitu sebanyak 113 kasus (Dinas Kesehatan Kabupaten Ciamis, 2018).

Ibu hamil KEK akan memiliki dampak diantaranya bayi yang dilahirkan mengalami BBLR dan mempunyai risikorisiko yang fatal misalnya, bayi mengalami gizi kurang, kematian bayi, gangguan terhadap pertumbuhan anak. Pencegahan yang dapat dilakukan ibu adalah dengan mengkonsumsi jumlah 
energi kalori yang cukup (nasi, ubi, dll) dan juga vitamin-vitamin serta mineral yang ada dalam buah-buahan, sayursayuran, lauk-pauk maupun dalam susu. Ibu hamil yang mengalami KEK mempunyai risiko antaralain, dapat mempengaruhi proses pertumbuhan janin, menimbulkan keguguran, abortus dan bayi lahir mati (Departemen Gizi dan Kesehatan masyarakat FKMUI, 2012).

KEK menyebabkan tergangunya kesehatan ibu ataupun janin yang dikandungnya. Ibu hamil KEK akan mengalami keluhan seperti kelelahan terus-menerus, merasa kesemutan, muka pucat. Sementara, janin yang tidak tumbuh maksimal akan menyebabkan bayi yang dilahirkan mengalami berat badan lahir rendah, perkembangan organ janin akan terganggu, kejadian tersebut akan mempengaruhi pada kemampuan belajar, kemampuan kognitif, anak cenderung berisiko mengalami kecacatan, serta dapat berisiko bayi yang dilahirkan mati, hal yang bisa terjadi pada janin yang dikandung oleh ibu yang KEK diantarannya keguguran (Kristiyanasari, 2014).

Berdasarkan data dan hasil pra survey di atas maka, peneliti tertarik untuk melakukan penelitian tentang Hubungan Kurang Energi Kronis (KEK) pada Ibu Hamil dengan Kejadian Berat Bayi Lahir Rendah (BBLR) di Wilayah Kerja Puskesmas Rajadesa Tahun 2019.

\section{METODE PENELITIAN}

Metode penelitian ini menggunakan metode penelitian deskriptif korelatif dengan rancangan penelitian cross sectional. Menurut Notoatmodjo (2011) bahwa cross sectional adalah suatu penelitian untuk mempelajari sistematika korelasi atau hubungan antara faktor-faktor resiko, dimana variabel independen (variabel risiko) dan variabel dependen (variabel akibat) akan dikumpulkan dalam waktu yang bersamaan (Arikunto, 2016) $)^{8,10}$.

Populasi dalam penelitian ini yaitu seluruh ibu hamil TM III di Puskesmas Rajadesa tahun 2018 yang berjumlah 66 orang. Jumlah sampel pada penelitian ini yaitu seluruh ibu hamil TM III di Puskesmas Rajadesa tahun 2018 yang berjumlah 66 orang. Dalam penelitian ini instrumen yang digunakan untuk pengambilan data adalah formulir lembar ceklis untuk mengambil data ibu selama kehamilannya dan pemeriksaan kehamilan dengan menggunakan LILA dan dari pengukuran ini akan didapatkan data yang dimasukan di dalam lembar ceklis, untuk data BBLR pada bayi juga mengunakan lembar ceklis dimana pada saat bayi dilahirkan datannya akan di catat apakah termasuk kedalam BBLR atau tidak BBLR.

Cara pengumpulan data yang digunakan oleh penulis pada penelitian ini adalah dengan menuganakan data primer, dimana ibu hamil trimester III di Puskesmas Rajadesa dijadikan sampel. Pada penelitian ini, rancangan analisis yang digunakan adalah analisis univariat dan juga bivariat yang bertujuan untuk mendeskripsikan masing-masing variabel yang digunakan dalam penelitian ini dengan melihat distribusi frekuensi dengan ukuran persentase/proporsi pada setiap variabelnya dan juga menghubungkan antara variabel penelitian (Notoatmodjo, 2014).

Analisis Univariat yaitu analisis yang dilakukan terhadap tiap variabel dari hasil penelitian. Analisis Bivariat yaitu analisis yang dilakukan terhadap 2 variabel yang diduga berhubungan atau berkorelasi ${ }^{5}$. Dalam analisis dapat dilakukan pengujian statistik dengan Chi Square.

\section{HASIL PENELITIAN}

Analisis Univariat

a. Kejadian KEK di Wilayah Kerja Puskesmas Rajadesa

Tabel 1

Distribusi Frekuensi Responden Berdasarkan Kejadian KEK 
Di Wilayah Kerja Puskesmas Rajadesa Tahun 2019

\begin{tabular}{|c|c|c|}
\hline Kejadian KEK & $\mathbf{F}$ & $\%$ \\
\hline Tidak KEK & 35 & 53 \\
\hline KEK & 31 & 47 \\
\hline Total & 66 & 100 \\
\hline
\end{tabular}

Berdasarkan tabel 1 distribusi frekuensi responden berdasarkan kejadian KEK diketahui bahwa lebih dari setengahnya responden tidak mengalami kejadian KEK sebanyak 35 orang (53\%) dan kurang dari sertengahnya responden mengalami kejadian KEK sebanyak 31 orang (47\%).

b. Kejadian BBLR di Wilayah Kerja Puskesmas Rajadesa Tahun 2019

Tabel 2

Distribusi Frekuensi Responden Berdasarkan Kejadian BBLR

Di Wilayah Kerja Puskesmas Rajadesa Tahun 2019

\begin{tabular}{|c|c|c|}
\hline Kejadian BBLR & $\mathbf{F}$ & $\%$ \\
\hline Tidak BBLR & 41 & 62,1 \\
\hline BBLR & 25 & 37,9 \\
\hline Total & 66 & 100 \\
\hline
\end{tabular}

Berdasarkan tabel 2 distribusi frekuensi responden berdasarkan kejadian BBLR diketahui bahwa sebagian kecil responden mengalami kejadian BBLR sebanyak 41 orang $(62,1 \%)$ dan sebagian besar responden tidak mengalami kejadian BBLR sebanyak 25 orang $(37,9 \%)$.

\section{Analisis Bivariat}

a. Hubungan Kejadian KEK dengan Kejadian BBLR di Wilayah Kerja Puskesmas Rajadesa Tahun 2019

Tabel 3

Distribusi Frekuensi Responden Berdasarkan Kejadian KEK dengan
Kejadian BBLR di Wilayah Kerja Puskesmas

Rajadesa Tahun 2019

\begin{tabular}{cccccccc}
\hline & \multicolumn{4}{c}{ Kejadian BBLR } & & & \\
\cline { 2 - 5 } $\begin{array}{c}\text { Kejadian } \\
\text { KEK }\end{array}$ & $\begin{array}{c}\text { Tidak } \\
\text { BBLR }\end{array}$ & \multicolumn{2}{c}{ BBLR } & & Total & $\begin{array}{c}\text { P } \\
\text { Value }\end{array}$ \\
\cline { 2 - 6 } & $\mathbf{F}$ & $\mathbf{\%}$ & $\mathbf{f}$ & $\mathbf{\%}$ & $\mathbf{F}$ & $\mathbf{\%}$ & \\
\hline Tidak & 30 & 85,7 & 5 & 14,3 & $\mathbf{3 5}$ & $\mathbf{1 0 0}$ & $\mathbf{0 , 0 0 0}$ \\
KEK & 11 & 35,5 & 20 & 64,5 & $\mathbf{3 1}$ & $\mathbf{1 0 0}$ & \\
KEK & 41 & 62,1 & 25 & 37,9 & $\mathbf{6 6}$ & $\mathbf{1 0 0}$ & \\
\hline Total & & & & & & & \\
\hline
\end{tabular}

Berdasarkan tabel 3 dapat dilihat bahwa dari 35 responden yang tidak mengalami kejadian KEK diketahui sebagian besar responden tidak mengalami kejadian BBLR sebanyak 30 orang $(85,7 \%)$ dan sebagian kecil responden mengalami kejadian BBLR sebanyak 5 orang (14,3\%). Sedangkan dari 31 responden yang mengalami kejadian KEK diketahui kurang dari setengahnya responden tidak mengalami kejadian BBLR sebanyak 11 orang $(35,5 \%)$ dan lebih dari setengahnya responden mengalami kejadian BBLR sebanyak 20 orang $(64,5 \%)$. Berdasarkan hasil uji statistik Chi Square, diketahui bahwa nilai $\mathrm{P}$ sebesar 0,000 lebih kecil dari nilai $\alpha(0,05)$, sehingga dapat disimpulkan bahwa terdapat hubungan antara kejadian KEK dengan kejadian BBLR.

\section{PEMBAHASAN}

\section{Kejadian BBLR di Wilayah Kerja Puskesmas Rajadesa Tahun 2019}

Berdasarkan tabel 2 distribusi frekuensi responden berdasarkan kejadian BBLR diketahui bahwa sebagian kecil responden mengalami kejadian BBLR sebanyak 41 orang $(62,1 \%)$ dan sebagian besar responden tidak mengalami kejadian BBLR sebanyak 25 orang $(37,9 \%)$.

Ibu hamil yang semulanya normal secara tiba-tiba dapat berisiko tinggi hal ini dikarenakan kehamilan yang bersifat dinamis. Apabila ibu hamil berstatus kesehatan yang buruk, misalnya ibu menderita anemia maka bayi yang 
nantinya dilahirkan akan berisiko lahir dengan berat badan rendah, jika bayi lahir dengan BBLR maka akan berisiko kesakitan seperti infeksi pada saluran pernafasan dan risiko kematian. Pendarahan pada saat proses persalinan ataupun pasca persalinan, gangguan kesehatan, bahkan kematian merupakan risiko ibu hamil yang menderita anemia 11.

Salah satu cara untuk menilai status gizi ibu hamil yaitu dengan melakukan pengukuran antropometri. Kenaikan berat badan pada ibu hamil dan pengukuran LILA selama kehamilan paling sering digunakan. LILA adalah antropometri yang dapat menggambarkan keadaan status gizi pada ibu hamil dan untuk mengetahui risiko KEK atau gizi kurang. Ibu yang memiliki ukuran LILA dibawah $23,5 \mathrm{~cm}$ berisiko melahirkan bayi BBLR (berat badan lahir rendah).

Apabila pada awal kehamilan ibu memiliki LILA ataupun IMT yang normal tetapi berat badan ibu tidak bertambah seperti yang dianjurkan, maka ibu tersebut berisiko untuk melahirkan bayi yang BBLR. Selain itu, menurut Assefa, et al. (2012), kekurangan energi kronis maupun akut memiliki hubungan dan pengaruh dengan berat lahir bayi, namun kekurangan energi akut memiliki efek yang lebih nyata dibandingkan dengan kekurangan energi kronis.

Ibu hamil yang sudah mengalami KEK disarankan untuk meningkatkan asupan gizinya dengan makanan yang tinggi kalori dan tinggi protein serta mendapatkan makanan tambahan dari pihak Puskesmas secara gratis bagi yang tidak mampu atau miskin ${ }^{7}$.

Anggraini et al. (2014) telah melakukan penelitian dan menyimpulkan bahwa LILA dan BBLR memiliki hubungan yang signifikan. Selain itu, ibu hamil yang memiliki LILA $<23,5 \mathrm{~cm}$ berisiko 4,3 kali lebih besar untuk melahirkan bayi BBLR.
Ohlsson dan Shah (2018) mengatakan bahwa tingginya kejadian KEK pada ibu yang melahirkan berat bayi lahir rendah (BBLR) disebabkan karena KEK merupakan kekurangan energi dalam jangka waktu yang cukup lama.

Penelitian ini juga sejalan dengan penelitian tentang hubungan status gizi ibu hamil dengan kejadian BBLR di wilayah Puskesmas Minggir Kabupaten Sleman. Hasil dari uji Chi Square menunjukkan adanya hubungan antara status gizi ibu hamil dengan kejadian BBLR di Puskesmas Minggir. Hubungan sebesar 0.000 , yang berarti $\mathrm{p}<0,05$ maka dapat disimpulkan bahwa terdapat hubungan antara status gizi ibu hamil dengan kejadian BBLR di Puskesmas Minggi Sleman.

\section{Kejadian KEK di Wilayah Kerja Puskesmas Rajadesa Tahun 2019}

Berdasarkan tabel 1 distribusi frekuensi responden berdasarkan kejadian KEK diketahui bahwa lebih dari setengahnya responden tidak mengalami kejadian KEK sebanyak 35 orang (53\%) dan kurang dari sertengahnya responden mengalami kejadian KEK sebanyak 31 orang $(47 \%)$.

KEK adalah penyebabnya dari ketidakseimbangan antara asupan untuk pemenuhan kebutuhan dan pengeluaran energi (Departemen Gizi dan Kesmas FKM UI, 2015). KEK atau Kurang Energi Kronis mempunyai istilah lain yaitu Kurang Energi Protein (KEP) yang ditujukn untuk wanita yang kurus akibat dari kurang energi kronis, definisi ini diperkenalkan oleh World Organization (WHO).

Ibu hamil dengan cukup energi akan naik berat badannya sesuai umur kehamilan dan bayi lahir sehat. Jika awal kehamilan menderita kondisi gizi kurang, maka kenaikan berat badan harus dipertimbangkan sesuai dengan defisit berat badan, jadi ibu hamil yang mederita 
KEK harus mengalami kenaikan berat badan yang lebih besar dari ibu hamil normal $^{13}$.

Ibu yang tergolong KEK yaitu ibu yang mengalami kekurangan energi dalam waktu yang lama, bahkan sejak sebelum masa kehamilan. Asupan gizi yang tidak adekuat saat masa implantasi embrio dapat berakibat fatal bagi perkembangan janin di trimester selanjutnya. Padahal, sebelum dan saat hamil, ibu membutuhkan asupan gizi yang optimal untuk mempersiapkan dan menunjang pertumbuhan serta perkembangan janin, jika ibu mengalami kekurangan gizi maka asupan gizi yang diberikan untuk janin juga akan sulit untuk terpenuhi, akibatnya terjadi hambatan pertumbuhan janin dan berat bayi lahir yang rendah.

Ibu hamil yang menderita KEK dapat mengakibatkan ukuran plasenta menjadi lebih kecil sehingga transfer oksigen dan nutrisi ke janin jadi berkurang. Dampaknya adalah ibu tersebut akan melahirkan bayi kecil atau BBLR. Untuk mencegah risiko KEK pada ibu hamil, diharapkan semua wanita usia subur, sebelum hamil sudah mempunyai gizi yang baik (LILA 23,5 cm). Apabila hal ini belum tercapai sebaiknya kehamilan ditunda terlebih dahulu agar tidak melahirkan bayi BBLR dan risiko lainnya (Supariasa, 2015).

Ketidakseimbangan antara asupan untuk pemenuhan kebutuhan dan pengeluaran energi merupakan penyebab dari KEK. Ketidakseimbangan pangan secara musiman atau secara kronis di tingkat rumah tangga dan beban kerja ibu hamil yang berat juga termasuk penyebab KEK yang sangat sering terjadi (Sri Widati, 2017).

Asumsi peneliti bahwa dalam menanggulangi KEK pada ibu hamil dan memperkecil risiko BBLR maka diperlukan upaya mempertahankan kondisi gizi yang baik pada ibu hamil antara lain melalui pencegahan dan pengobatan yaitu mengusahakan agar ibu hamil memeriksakan kehamilannya secara rutin dan lebih awal, perlu adanya penjaringan dan deteksi Wanita Usia Subur (WUS) yang mempunyai risiko KEK dan Anemia sehingga faktor risiko tersebut dapat diketahui dan dilakukan penangananan sedini mungkin.

Penelitian dari Susilani A, (2014) mengatakan bahwa ibu hamil memerlukan asupan gizi yang baik agar janin dapat tumbuh dengan baik, tidak mengalami hambatan, dan melahirkan bayi dengan berat badan yang normal. Apabila kondisi kesehatan ibu baik, sistem reproduksi normal, tidak mengalami gangguan gizi baik pada saat pra hamil maupun saat hamil, ibu tidak menderita penyakit apapun, maka ibu akan melahirkan bayi yang lebih sehat dan lebih besar daripada ibu dengan kondisi kehamilan sebaliknya.

Berdasarkan penelitian yang dilakukan oleh Sri Widati, 2017 tentang faktor risiko status gizi ibu terhadap kejadian BBLR di Puskesmas Kokap I Kabupaten Kulon Progo. Hasil dari uji statistik dengan Kai Kuadrat didapatkan nilai psebesar $0,001(<0,05)$ artinya bahwa ada hubungan antara status gizi ibu hamil dengan berat badan lahir.

Berdasarkan analisis odds ratio (OR) dengan tingkat kepercayaan $95 \%$, didapat nilai OR 5,898 (CI 95\%; 2,007 17,333) artinya ibu yang berstatus gizi KEK saat hamil mempunyai risiko 5,9 kali lebih besar melahirkan bayi BBLR dibandingkan dengan ibu yang saat hamil tidak KEK.

\section{Hubungan Kejadian KEK dengan Kejadian BBLR}

Berdasarkan tabel 4.3 dapat dilihat bahwa dari 35 responden yang tidak mengalami kejadian KEK diketahui sebagian besar responden tidak mengalami kejadian BBLR sebanyak 30 orang $(85,7 \%)$ dan sebagian kecil responden mengalami 
kejadian BBLR sebanyak 5 orang $(14,3 \%)$.

Sedangkan dari 31 responden yang mengalami kejadian KEK diketahui kurang dari setengahnya responden tidak mengalami kejadian BBLR sebanyak 11 orang $(35,5 \%)$ dan lebih dari setengahnya responden mengalami kejadian BBLR sebanyak 20 orang $(64,5 \%)$.

Berdasarkan hasil uji statistik Chi Square, diketahui bahwa nilai $\mathrm{P}$ sebesar 0,000 lebih kecil dari nilai $\alpha(0,05)$, sehingga dapat disimpulkan bahwa terdapat hubungan antara kejadian KEK dengan kejadian BBLR.

Ketidakseimbangan antara asupan untuk pemenuhan kebutuhan dan pengeluaran energi merupakan penyebab KEK secara spesifik ${ }^{7}$.

Jika ibu hamil menderita gizi buruk atau KEK , kondisi ini akan sangat berpengaruh pada pertumbuhan janin yang dikandungnya. Pengaruh ini akan menentukan berat badan lahir bayinya yang akan kurang dari seharusnya. Berat badan bayi yang rendah ini akan sangat berpengaruh terhadap kematian bayi yang lebih besar. Sebuah hasil studi di Guatemala (Amerika Serikat) memperlihatkan bahwa semakin rendah berat badan bayi baru lahir semakin besar angka kematian ${ }^{7}$.

Hasil penelitian diatas ditunjang juga oleh penelitian yang dilakukan oleh Kartikasari (2011) tentang hubungan KEK dengan status gizi ibu hamil di Puskesmas Bangetayu Kota Semarang. Uji statistik menunjukkan antara kejadian KEK dengan kejadian BBLR diperoleh hasil penghitungan diperoleh nilai $\mathrm{p}=0,036 \quad(\mathrm{p}<0,05), \quad$ sehingga dapat disimpulkan ada hubungan yang signifikan KEK pada ibu hamil dengan BBLR.

\section{SIMPULAN DAN SARAN}

Berdasarkan hasil penelitian dan pembahasan maka dapat disimpulkan Hubungan Kurang
Energi Kronis (KEK) pada Ibu Hamil dengan Kejadian Berat Bayi Lahir Rendah (BBLR) di Wilayah Kerja Puskesmas Rajadesa Tahun 2019 adalah sebagai berikut :

1. Diketahui bahwa lebih dari setengahnya responden tidak mengalami kejadian KEK sebanyak 35 orang (53\%).

2. Diketahui bahwa lebih dari setengahnya responden mengalami kejadian BBLR sebanyak 41 orang $(62,1 \%)$.

3. Berdasarkan hasil uji statistik Chi Square, diketahui bahwa nilai P sebesar 0,000 lebih kecil dari nilai $\alpha(0,05)$, sehingga dapat disimpulkan bahwa terdapat hubungan antara kejadian KEK dengan kejadian BBLR.

\section{DAFTAR PUSTAKA}

1. Dinkes Ciamis, 2017. Profil Kesehatan Kab. Ciamis, 2017. Kabupaten Ciamis.

2. Dinkes Jawa Barat, 2017. Laporan Akuntabilitas Kinerja Instansi Pemerintahan. LAKIP Propinsi Jawa Barat. Bandung.

3. Kemenkes, 2015. Survei Demografi dan Kesehatan Indonesia (SDKI) 2015. Jakarta: Badan Pusat Statistik.

4. Universitas Indonesia, 2013. Departemen Gizi dan Kesehatan Masyarakat. Fakultas Kesehatan Masyarakat Universitas Indonesia, 2013. Gizi dan Kesehatan Masyarakat. Jakarta : Rajawali Pers.

5. Puskesmas Rajadesa, 2018. Dinas Kesehatan Kabupaten Ciamis, Profil Kesehatan Puskesmas Rajadesa dan Laporan Bulanan Puskesmas. Ciamis.

6. Dinkes Jawa Barat, 2017. Laporan Akuntabilitas Kinerja Instansi Pemerintahan. LAKIP Propinsi Jawa Barat. Bandung.

7. Kristiyanasari, 2010. Gizi Ibu Hamil. Yogyakarta : Nuha Medika.

8. Riskesdas, 2013. Survey Demografi dan Kesehatan Indonesia. 
9. Arikunto, 2016. Prosedur Penelitian Suatu Pendekatan Praktik. Jakarta : Rineka Cipta.

10. Notoatmodjo, 2010. Promosi Kesehatan Teori dan Aplikasinya. Jakarta : Rineka Cipta.

11. Departemen Kesehatan RI, 2014. Pedoman Pemantauan Wilayah Setempat Gizi. Jakarta : Departemen Kesehatan RI.

12. Marni, 2013. Gizi Dalam Kesehatan Reproduksi. Yogyakarta : Pustaka Pelajar.

13. Supariasa, 2012. Penilaian Status Gizi. Jakarta : EGC. 